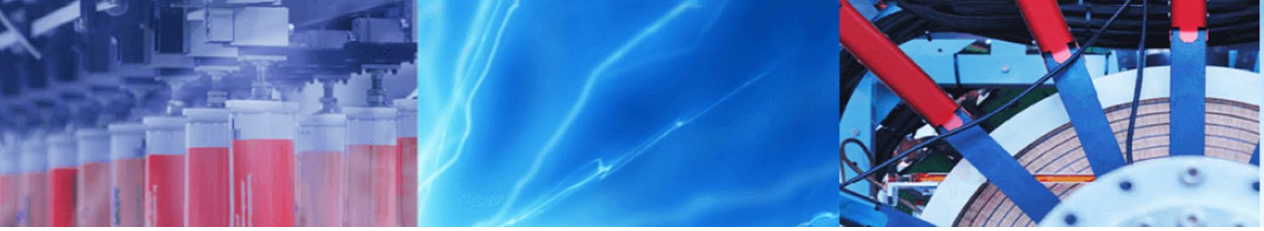

Research Article

\title{
Potential utilization of artisanal gold-mine tailings as geopolymeric source material: preliminary investigation
}

\author{
John Paul J. Aseniero ${ }^{1}$ Einstine M. Opiso ${ }^{2} \cdot$ Marybeth Hope T. Banda $^{2} \cdot$ Carlito B. Tabelin $^{3}$
}

(c) Springer Nature Switzerland AG 2018

\begin{abstract}
In this study, chemical and mineralogical characterizations of gold-mine tailings in key mining areas in Mindanao, Philippines were investigated for possible utilization as geopolymeric source material. Results of X-ray fluorescence (XRF) and energy dispersive X-ray spectroscopy (EDS) showed that the mine tailings samples have significant amounts of silicon, aluminum and calcium, which are crucial elements needed for geopolymerization. This was confirmed by the IR spectroscopic and mineralogical characteristics of the tailings where vibration bonds and minerals associated with Al and Si such as kaolinite and zeolite are detected. These minerals are already established as indicators for a material to be a good feedstock for geopolymerization. Furthermore, one of the tailings samples had an Si/Al ratio of 4.81, which was close to the recommended value of 3.0 for geopolymerization. The compressive strength of the synthesized geopolymer bricks gained an average of $5.48 \mathrm{MPa}$. The results suggested that gold mine tailings from key mining areas in Mindanao, Philippines could be used as geopolymer source material.
\end{abstract}

Keywords Gold-mine tailings · Geopolymerization · Stabilization · Utilization

\section{Introduction}

The Philippines is considered as one of the world's top producers of gold and ranked third in the world in terms of estimated gold deposit (around 5.02 billion tons) [1]. Due to the high global gold demand, the gold mining industry has brought significant economic activity to the country, but most of this is done by artisanal small-scale miners (SSM). Between 2005 and 2014, about $63 \%$ of the gold produced in the Philippines came from SSM according to the Mines and Geoscience Bureau (MGB) [2]. The amounts of mine tailings generated by SSM are also substantial, which are usually dumped in designated tailing ponds with minimal treatment [3].

The proliferation of SSM in the Philippines has caused the rapid increase in artisanal gold mine tailings disposed of every year that poses considerable risks to the health of individuals living around the mine sites as well as the surrounding ecosystems. It is not only important to decontaminate these mine tailings to prevent the release of toxic elements that they contain but also to find possible applications of these millions of tons of mine tailings after decontamination [3]. Utilization of waste materials in construction application is a sustainable manner in minimising the impact of these waste to the environment such as fly ash [4], bagasse ash [5], marble [4], etc.

Several authors have reported that some tailings could be used in the construction industry depending on their mineralogical composition, particle size distribution and mechanical properties [6-10]. For example, a recent study [11] showed that it is possible to utilise gold-mine tailings as an additive of Portland cement during construction.

Einstine M. Opiso, einstineopiso@cmu.edu.ph; John Paul J. Aseniero, jpaseniero@gmail.com; Marybeth Hope T. Banda, marybethhope@ gmail.com; Carlito B. Tabelin, carlito.tabelin@gmail.com | ${ }^{1}$ Materials Science Research Group, Physics Department, Central Mindanao University, Bukidnon, Philippines. ${ }^{2}$ Geo-environmental Engineering Group, Civil Engineering Department, College of Engineering, Central Mindanao University, Bukidnon, Philippines. ${ }^{3}$ Division of Sustainable Resources Engineering, Faculty of Engineering, Hokkaido University, Sapporo, Japan. 
These authors reported that $5-15 \%$ of gold-mine tailings to cement had negligible effects on the final mechanical properties of concrete. Other authors have also reported that mine tailings together with Portland cement and various soils (e.g., black cotton soils and red soils) could be used to make bricks [12]. Although significant results in terms of compressive strength, linear shrinkage and water absorption have been obtained by these previous studies [12], detailed evaluations of how the mineralogical and chemical compositions of mine tailings affect the resulting mechanical properties of the product, which are crucial for safety assessment of bricks and other materials for construction purposes, are still limited.

Another possible approach of preventing the release of hazardous (e.g., heavy metals) and toxic elements (e.g., mercury and arsenic) from these wastes and at the same time recycling them into something of economic value is via geopolymerization. Geopolymerization is a process of crosslinking $\mathrm{AlO}_{4}$ and $\mathrm{SiO}_{4}$ tetrahedra in alumino-silicaterich materials via a low-temperature activation process using strongly alkaline solutions (e.g., $\mathrm{NaOH}$ ) [13]. See [14], for example, used slag-based geopolymers to immobilise lead $(\mathrm{Pb})$ and copper $(\mathrm{Cu})$, which remained stable even under moderately aggressive leaching conditions. Fixation of heavy metals via geopolymerization could occur via their participation in the balancing of negative charge attributed to $\mathrm{AlO}_{4}$ and $\mathrm{SiO}_{4}$ in the geopolymer matrix as well as through sorption reactions $[15,16]$. When goldmine tailings have the desired properties like substantial amounts of amorphous silicon (Si) and aluminum (Al) phases and alumino-silicate/clay minerals (e.g., feldspars, kaolinite and montmorillonite), they are potentially suitable raw materials for geopolymeric products with considerably high compressive strength and long-term durability $[17,18]$. Some additives added to mine tailings could further improve the final mechanical properties of geopolymerization products likely via changes in the $\mathrm{Si}-\mathrm{Al}$ ratio of the source material. For instance, [19] reported that the unconfined compressive strength of tailings from a goldcopper mine significantly increased after geopolymerization with the addition of aluminum sludge because the optimum $\mathrm{Si}-\mathrm{Al}$ and sodium ( $\mathrm{Na}$ )-Al ratios were achieved. Aside from aluminum sludge, cement kiln dust (CKD) has also been reported to enhance not only the physical and mechanical properties but also the durability of geopolymer bricks made from mine tailings [20].

The $\mathrm{SiO}_{2}$ and $\mathrm{Al}_{2} \mathrm{O}_{3}$ contents of source material typically determine the final $\mathrm{Si}$ to $\mathrm{Al}$ ratio of geopolymer products. Reddy et al. [21] obtained optimum compressive strengths when the $\mathrm{SiO}_{2}$ and $\mathrm{Al}_{2} \mathrm{O}_{3}$ were in the range of 45-55 and $22-28 \%$, respectively, while the combined amounts of $\mathrm{CaO}$ and $\mathrm{Fe}_{2} \mathrm{O}_{3}$ did not exceed $20 \%$. It is important to note that although high calcium content might lead to higher compressive strengths, workability could suffer due to rapid hardening of the system as a consequence of calcium-silicate-hydrate (C-S-H) or calcium-alumino-silicate-hydrate (C-A-S-H) formation.

Our previous study showed that gold-mine tailings from key areas in Mindanao, Philippines were relatively fine $(0.2-0.4 \mu \mathrm{m})$ because they underwent ball milling twice to improve the liberation of gold [12]. Small-sized particles are favoured for construction material applications because fineness has a strong positive effect on the early strength development of concrete [22]. Similarly, finer sized minerals have been reported to enhance the mechanical properties of geopolymer products [13], so the particle size distribution of these gold-mine tailings are already suitable for geopolymer applications. Another important criterion for the application of gold-mine tailings as geopolymer source material is the detailed analyses of their chemical and mineralogical properties. Unfortunately, studies on the characterization of gold-mine tailings from different artisanal mines in the Philippines especially for the purpose of possible applications as geopolymer source material remain limited. In this study, the chemical and mineralogical compositions of gold-mine tailings from key mining areas of Mindanao, Philippines were determined and their potential as geopolymer source material was investigated. The gold-mine tailing samples were characterised using X-ray fluorescence (XRF), field emission scanning electron microscopy with energy dispersive X-ray spectroscopy (FESEM-EDS), Fourier transform infrared spectroscopy (FTIR) and X-ray powder diffraction (XRD). The tailing samples were then used as geopolymer source material and the mechanical strength of the product was elucidated using a universal testing machine.

\section{Methodology}

\subsection{Sample collection and characterization}

The gold-mine tailings samples were obtained from Barangay Gango (Libona, Bukidnon), Barangay Del Pilar (Cabadbaran City, Agusan del Norte), and Barangay Mt. Diwata (Mt. Diwalwal) (Monkayo, Compostela Valley). About 3-7 kg of gold-mine tailings was collected in selected old tailings pond and stored following the standard procedure in sample collection. Samples were labeled as Li-BM for the tailings of ball mills from Libona, D-CIP for residues of the carbon-in-pulp process from Del Pilar, Cabadbaran, W-BM for the ball mill tailings from Mt. Diwata, and W-CIP for the carbon-in-pulp plant residues from Mt. Diwata. The specific details of the sampling locations and conditions of the disposal site could be referred to the previous study [12]. 
Chemical compounds and functional groups present in mine tailing samples were determined using $X$-ray Fluorescence (XRF EDX-720, Shimadzu Corporation, Japan) and Fourier Transform Infrared Spectrsocopy (FTIR-SPECTRUM ACSII PEDS 1.60, Perkin Elmer, USA), respectively. For the determination of mineralogical properties of mine tailings, an X-ray Diffraction (XRD-7000, Shimadzu Corporation, Japan) was used operating under the following conditions: scanning range of $2 \theta$ from $5^{\circ}$ to $70^{\circ}$, at $40 \mathrm{kV}, 20 \mathrm{~mA}$, step size of $0.02^{\circ}$, scanning speed of $2^{\circ}$ per minute and CuKa radiation. Surface topography of the gold-mine tailings was observed by Field Emission-Scanning Electron Microscopy (FESEM) while elemental analysis of the samples was done through Energy Dispersive X-ray Spectroscopy (EDS).

\subsection{Geopolymerization and mechanical properties of geopolymer materials from gold-mine tailings}

Exploratory synthesis of geopolymer using Carbon-in-pulp (CIP) residues as raw materials was carried out to assess for their future recycling and utilization potentials. A powdertype activator was used in this study because of its ease of handling compared to strong alkali solutions that are difficult to work with due to their high viscosity and very corrosive nature [21]. Preparation of the powder activator followed the procedure of [23] with slight modifications. In this study, lime sludge, a waste material from sugar refineries, was used as the source of calcium carbonate to make the process more environmentally friendly. Preparation of the powder activator was carried out by mixing lime sludge and $\mathrm{NaOH}$ solution (5 M), oven-drying the product for $8 \mathrm{~h}$, pulverizing and screening $(<75 \mu \mathrm{m})$. The CIP samples were mixed with dry activator and water in a planetary mixer. The mine tailings-to-dry activator ratio and water content were maintained at 1:1 by mass and $20 \%$, respectively. Five $50-\mathrm{mm}$-cube geopolymer specimens were cured under ambient conditions for 7 days and their unconfined compressive strengths were measured using a universal testing machine.

\section{Results and discussion}

\subsection{Chemical compositions of gold-mine tailings}

The chemical compositions of mine tailings shown in Table 1 indicate that $\mathrm{SiO}_{2}$ is the most abundant component of the samples, which varied from 52.2 to $77.3 \%$ by weight. Although all samples also contain $\mathrm{Al}_{2} \mathrm{O}_{3}, \mathrm{CaO}$ and $\mathrm{Fe}_{2} \mathrm{O}_{3}$, they are present in variable amounts (Table 1 ). The samples also contain minor to trace amounts of $\mathrm{K}_{2} \mathrm{O}$, $\mathrm{TiO}_{2}, \mathrm{MnO}, \mathrm{Cr}_{2} \mathrm{O}_{3}$ and $\mathrm{ZnO}$ (Table 1). Among the samples,
Table 1 Chemical compositions of gold-mine tailings (in wt\%)

\begin{tabular}{lcccl}
\hline $\begin{array}{l}\text { Chemical } \\
\text { formula }\end{array}$ & W-BM & W-CIP & P-CIP & Li-BM \\
\hline $\mathrm{SiO}_{2}$ & 77.3 & 59.8 & 52.2 & 55.7 \\
$\mathrm{Al}_{2} \mathrm{O}_{3}$ & 4.48 & 6.03 & 9.71 & 5.22 \\
$\mathrm{Fe}_{2} \mathrm{O}_{3}$ & 6.14 & 6.69 & 28.9 & 18.9 \\
$\mathrm{CaO}$ & 9.59 & 21.0 & 1.82 & 11.5 \\
$\mathrm{SO}_{3}$ & 1.13 & 2.31 & 1.98 & - \\
$\mathrm{K}_{2} \mathrm{O}$ & 0.86 & 3.11 & 2.70 & 1.82 \\
$\mathrm{TiO}_{2}$ & 0.173 & 0.588 & 1.67 & 0.862 \\
$\mathrm{MnO}$ & 0.100 & 0.226 & 0.258 & 0.666 \\
\hline
\end{tabular}

“_" means not detected

W-CIP had the highest $\mathrm{CaO}$ content $(21 \%)$ followed by Li-BM (11.5\%), W-BM (9.6\%) and D-CIP (1.8\%). Moreover, the amount of $\mathrm{Al}_{2} \mathrm{O}_{3}$ was highest in D-CIP (9.7\%) followed by W-CIP (6\%), Li-BM (5\%) and W-BM (4.5\%).

Except for $\mathrm{Al}_{2} \mathrm{O}_{3}$, the $\mathrm{X}$-ray Fluorescence (XRF) results showed that relative abundances of $\mathrm{SiO}_{2}, \mathrm{CaO}$ and $\mathrm{Fe}_{2} \mathrm{O}_{3}$ in the tailings samples are suitable for geopolymer application [12]. To increase the amount of $\mathrm{Al}_{2} \mathrm{O}_{3}$ in the samples, small amounts of aluminum-rich materials such as fly ash or aluminum sludge might be necessary [7]. In comparison, D-CIP showed very low $\mathrm{CaO}$ content and could be improved by adding locally sourced limestone. For the other mine tailings that have $\mathrm{CaO}$ contents more than $8 \%$, the use of sodium hydroxide together with water glass might be required to improve their compressive strengths during geopolymerization [24]. $\mathrm{CaO}$ in the sample should also be controlled because excessive amounts may hasten hardening during geopolymerization [25].

The amounts of $\mathrm{Fe}_{2} \mathrm{O}_{3}$ measured in D-CIP (29\%) and Li-BM (19\%) were significantly higher compared with those in W-BM and W-CIP. Although reports on the roles played by $\mathrm{Fe}$ or $\mathrm{Fe}_{2} \mathrm{O}_{3}$ during geopolymerization are limited, two recent studies reported that high Fe contents had negligible negative effects on the mechanical properties of geopolymers $[25,26]$ as well as in the compressive strengths of geopolymer mortars [26]. For future utilization of the Fe-rich mine tailings like those found in goldmines, however, a more thorough evaluation of the direct effects of iron-bearing minerals on the formation of poly ferro-sialate-siloxo or ferro-sialate-disiloxo binders ([Ca, $\left.\mathrm{Na}]-[-\mathrm{Fe}-\mathrm{O}-]_{\mathrm{x}}-[-\mathrm{Si}-\mathrm{O}-\mathrm{Al}-\mathrm{O}-]_{1-\mathrm{x}}-[-\mathrm{Si}-\mathrm{O}-]_{\mathrm{y}}\right)$ is required [27].

\subsection{X-ray diffraction analysis}

The X-ray Diffraction (XRD) patterns of samples from different gold-mining areas are shown in Fig. 1. Minerals like quartz, calcite, zeolite, birnessite, merrillite, vermiculite, 
Fig. 1 XRD patterns of the samples taken from Libona (Li-BM), Cabadbaran CIP Plant (P-CIP), Diwalwal Ball Mill (W-BM), and Diwalwal CIP Plant (W-CIP)

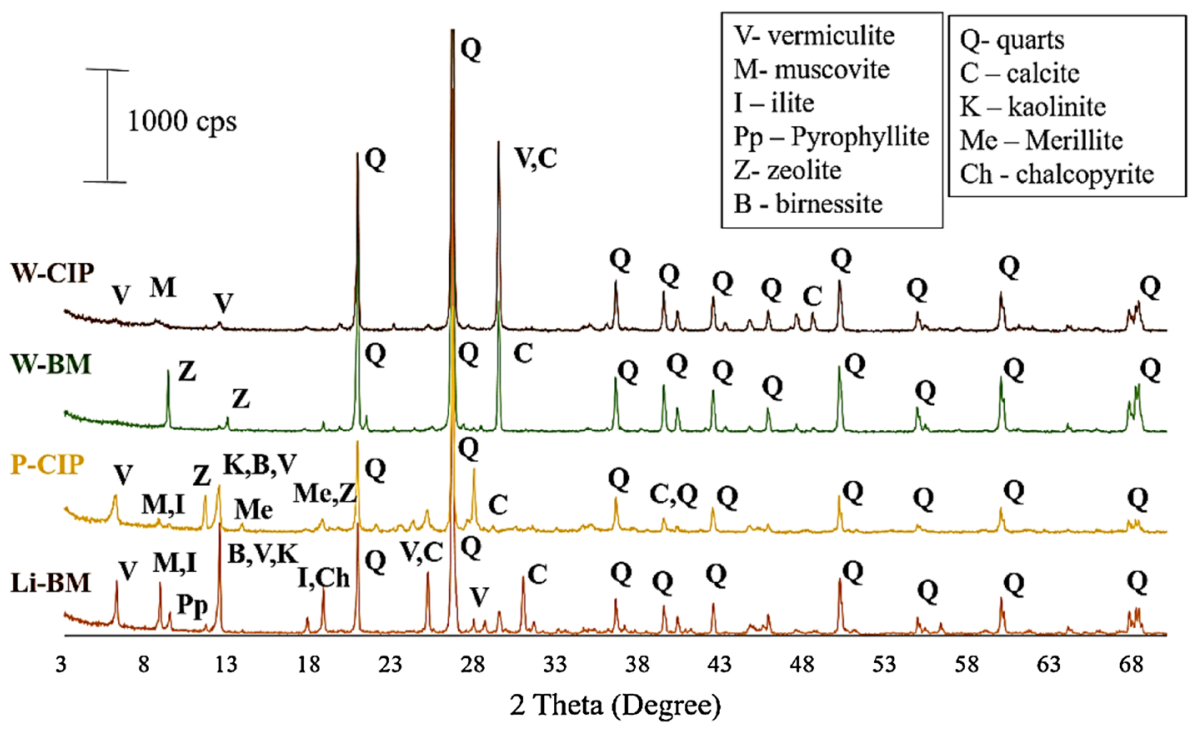

muscovite, illite, pyrophyllite, kaolinite and chalcopyrite were detected. The strongest peak intensities in all the patterns were that of quartz. The presence of calcite, which was detected in all samples, could be attributed to the use of lime in the gold-mining industry for the refinement of metals. Also, clay minerals occurring in the mining sites like vermiculite, muscovite, and illite were identified. Vermiculite is a phyllosilicate mineral that expands when heated and is composed of $\mathrm{Mg}, \mathrm{Fe}, \mathrm{Al}, \mathrm{Si}, \mathrm{H}$, and $\mathrm{O}$. Similarly, muscovite is a hydrated phyllosilicate mineral containing $\mathrm{K}, \mathrm{Al}, \mathrm{Si}, \mathrm{F}, \mathrm{H}$, and $\mathrm{O}$ while illite is a phyllosilicate of the mica group composed of $\mathrm{K}, \mathrm{Al}, \mathrm{Mg}, \mathrm{Fe}, \mathrm{Si}, \mathrm{H}$, and $\mathrm{O}$.

As listed in Table 2, vermiculite, illite and muscovite are the minerals containing aluminum detected in trace amounts in samples Li-BM, P-CIP and W-CIP. Kaolinite was observed in Li-BM and P-CIP whereas zeolite was detected in W-BM and P-CIP. Pyrophyllite was only detected in $\mathrm{Li}-\mathrm{BM}$. Among the samples, only P-CIP had a Si-Al ratio (4.8) close to the recommended Si-Al ratio (3.0) of potential geopolymer source materials. The other samples had very high $\mathrm{Si}-\mathrm{Al}$ ratios due to their high concentrations of $\mathrm{SiO}_{2}$ but relatively low concentrations of $\mathrm{Al}_{2} \mathrm{O}_{3}$. Controlling the $\mathrm{Si}-\mathrm{Al}$ ratio is very important in geopolymerization because this partly determines the resulting geopolymeric structure as well as the dissolution rates of $\mathrm{Si}$ and $\mathrm{Al}$ during activation [17].

Although the relationship between mineralogy and reactivity of individual minerals is extremely complex, there are known minerals detected in the tailings (i.e., kaolinite, zeolite and illite) that have been studied for geopolymerization. Xu and Deventer [28] reported that illite could be used as source material for geopolymers but its reaction mechanism(s) especially during the dissolution of $\mathrm{Al}$ and $\mathrm{Si}$ is still unclear. In comparison, kaolinite and zeolite had already been established as useful materials for geopolymerization [28-33]. Zeolite, for example, was reported by [31] to dissolve almost completely when sodium hydroxide was used as an activator and an amorphous geopolymer phase was formed together with some crystalline inclusion. Similarly, [32] reported that geopolymerization occurred when natural zeolite reacts with a mixture of sodium silicate and sodium hydroxide. For kaolinite, the main concern was the slower rate of Al dissolution that may require longer treatment time for interactions among the source materials to occur. However, [33] reported that controlling the $\mathrm{Na}_{2} \mathrm{O}$ content could improve the dissolution of kaolin materials. Unfortunately, very little information is available on the dissolution of $\mathrm{Si}$
Table 2 Trace aluminumbearing minerals and molar $\mathrm{Si}-\mathrm{Al}$ ratios of mine tailings

\begin{tabular}{llc}
\hline Mine tailings & Aluminum-bearing-minerals & $\begin{array}{c}\text { Molar Si-Al ratio } \\
\text { based on XRF }\end{array}$ \\
\hline Li-BM & Vermiculite, illite, muscovite, kaolinite, pyrophyllite & 9.42 \\
P-CIP & Vermiculite, illite, muscovite, kaolinite, Zeolite & 4.81 \\
W-CIP & Vermiculite, illite, muscovite & 8.75 \\
W-BM & Zeolite & 15.2 \\
\hline
\end{tabular}




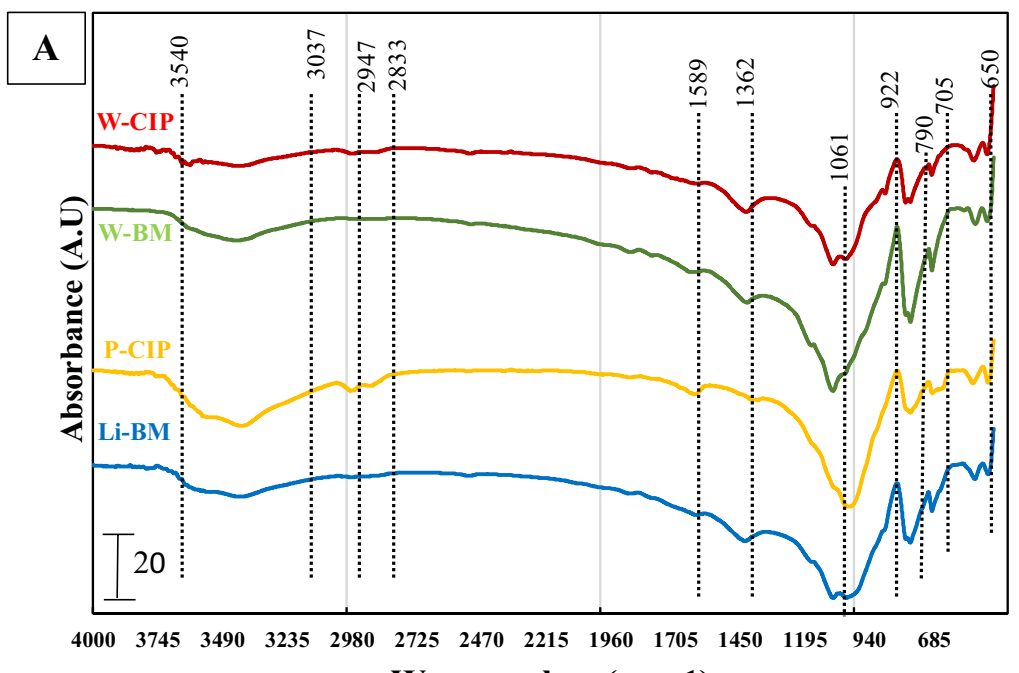

Wavenumber (cm -1)
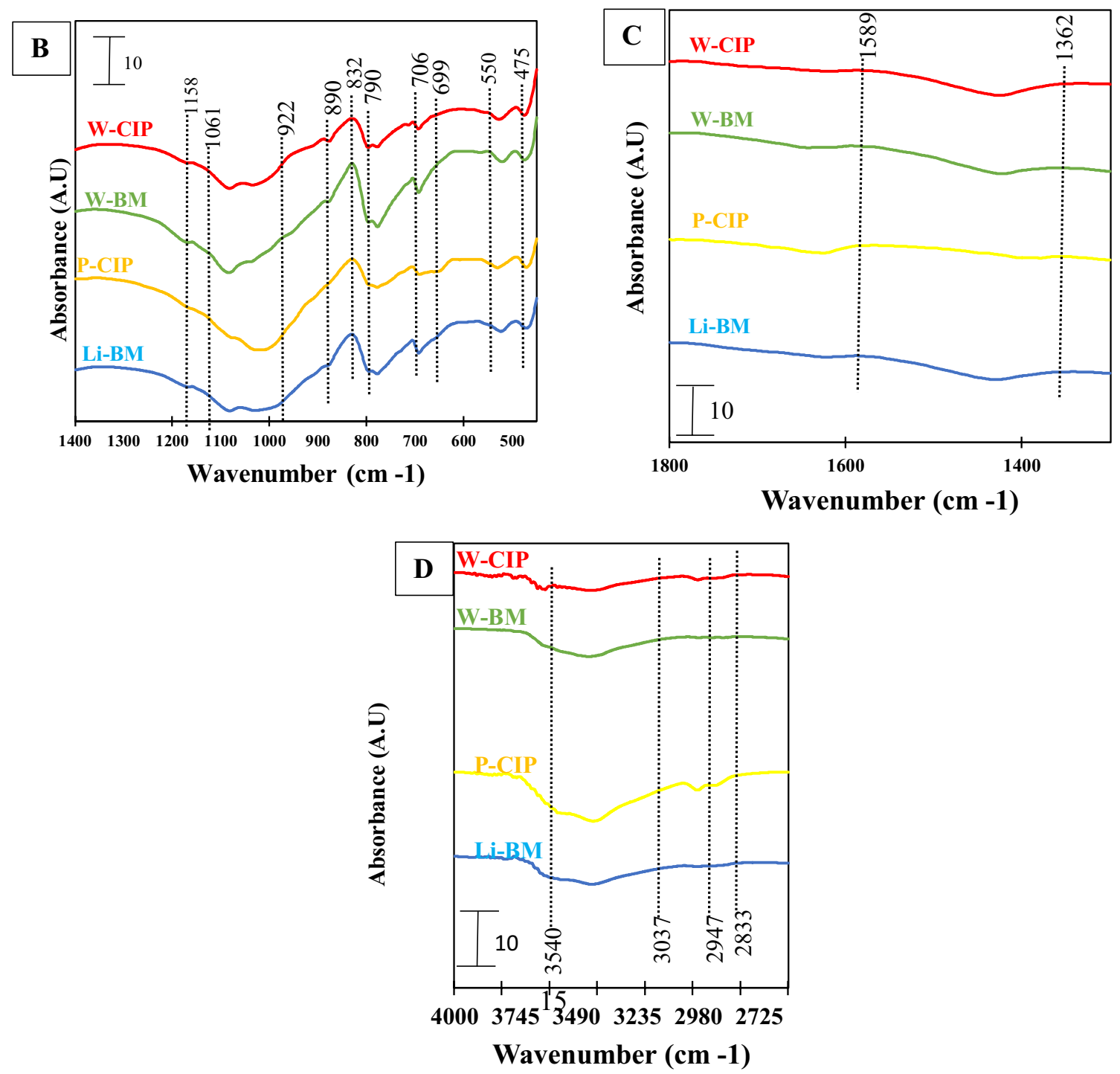

Fig. 2 FTIR spectra of samples from Libona (Li-BM), Del Pilar CIP (P-CIP), Diwalwal Ball Mill (W-BM), and Diwalwal CIP (W-CIP) at wavelengths: a full region, b 1450-450, c 1850-1250, and d 3850-2550 
and $\mathrm{Al}$ in minerals such as vermiculite, pyrophyllite and muscovite during geopolymerization.

\subsection{Fourier transform infrared spectroscopic analysis}

Shown in Fig. 2 are the FTIR spectra of the different mine tailings samples. The results corroborate the minerals and elemental composition detected in XRD and XRF analyses.

$\mathrm{Al}-\mathrm{OH}$ translational vibration observed at 784 and $694 \mathrm{~cm}^{-1}$ together with the $\mathrm{Si}-\mathrm{O}$ stretching bands around $1035 \mathrm{~cm}^{-1}$ could be attributed to the presence clay minerals in the tailings [34-36]. Furthermore, the absorption band around $620-600 \mathrm{~cm}^{-1}$ detected in Li-BM and P-CIP corresponds to the bending vibration of $\mathrm{O}-\mathrm{Al}-\mathrm{O}[37,38]$ while the absorption band around $3670-3550 \mathrm{~cm}^{-1}$ corresponds to $\mathrm{Al}-\mathrm{O}-\mathrm{H}$ stretching. Meanwhile, the $\mathrm{O}-\mathrm{H}$ deformation linked to $\mathrm{Al}^{3+}$ and $\mathrm{Mg}^{2+}$ at around $880-865 \mathrm{~cm}^{-1}$ was detected in $\mathrm{Li}-\mathrm{BM}$, and $\mathrm{D}-\mathrm{CIP}$ samples. Also, $\mathrm{Si}-\mathrm{O}-\mathrm{Al}$ stretching possibly linked to $\mathrm{Fe}-\mathrm{O}$ was detected at around $535 \mathrm{~cm}^{-1}$ [39]. These bonds could be attributed to the aluminium-bearing-minerals present in all samples such as muscovite, vermiculite, ilite and kaolinite which were detected in their mineralogical characteristics.

All gold-mine tailings samples showed strong absorption bands around $1175-1080$ and $800-780 \mathrm{~cm}^{-1}$, which are assigned to $\mathrm{Si}-\mathrm{O}$ asymmetrical stretching and symmetrical stretching, and the absorption band around $480-470 \mathrm{~cm}^{-1}$ that correspond to the $\mathrm{Si}-\mathrm{O}-\mathrm{Si}$ bending modes are characteristic IR signatures of quartz $[38,40$, 41]. The $\mathrm{O}-\mathrm{H}$ vibrational modes of the hydroxyl molecule in the tailings were observed at the absorption bands of around $1647-1632 \mathrm{~cm}^{-1}$ and $3450-3400 \mathrm{~cm}^{-1}$, which is attributed to the $\mathrm{O}-\mathrm{H}$ stretching from adsorbed water [35, 39]. Finally, the absorption bands around 1450-1400 and $2985-2900 \mathrm{~cm}^{-1}$ correspond to the $\mathrm{C}-\mathrm{H}$ stretching and symmetric stretch of $-\mathrm{CH}_{3}$ group respectively. Table 3 presents the summary of the IR absorption band positions together with their functional group assignments.

\subsection{FESEM-EDS analysis}

Results of the morphological characteristics of collected mine tailings samples (Fig. 3) show consistency with the results of [42]. All samples exhibited granular-shaped particles with large and small grain sizes. Tailings samples W-CIP (Fig. 4a), W-BM (Fig. 4b), and W-CIP (Fig. 4c) were composed mostly of rounded and elongated granular particles that are large and irregularly shaped while sample Li-BM (Fig. 4d) contained larger particles with regularly shaped grains. All samples packed closely with no interassemblage pore spaces, such that the overall positioning was random and exhibited flaky surface characteristics.

The majority of elements detected by EDS were in good agreement with the XRF results. Traces of elements such as $\mathrm{Al}, \mathrm{Fe}, \mathrm{Ca}, \mathrm{Mg}$ were also observed. The results also show that the EDS data for P-CIP tailings contain large amounts of $\mathrm{Fe}$, which agreed well with the XRF results. Silicon was

Table 3 Infrared band positions and their assignments (Saikia et al. [39]; Li et al. [35, 36]; Voll et al. [37]; Tabelin et al. [40]; Hanna [41]; Saikia et al. [34])

\begin{tabular}{llllll}
\hline $\begin{array}{l}\text { Theoretical wave- } \\
\text { number }\left(\mathrm{cm}^{-1}\right)\end{array}$ & \multicolumn{2}{l}{ Wavenumber $\left(\mathrm{cm}^{-1}\right)$} & & Assignments \\
\cline { 2 - 4 } & Li-BM & W-CIP & W-BM & P-CIP & \\
\hline $3670-3550$ & 3636.2 & 3621.4 & 3636.2 & 3576 & Al-O-H stretching \\
$3450-3400$ & 3406 & 3413 & 3435 & 3406 & H-O-H stretching of absorbed water \\
$2995-2950$ & - & 2990.5 & - & 2983 & C-H stretching vibrations \\
$2985-2900$ & - & 2989.9 & - & 2986 & Symmetric stretch of $-\mathrm{CH}_{3}$ group \\
$\sim 1645$ & 1640 & 1632 & 1647 & 1639 & O-H stretching of adsorbed water \\
$1450-1400$ & 1431 & 1424 & 1424.3 & 1402 & C-H stretching \\
$1589-1382$ & $1589-1382$ & $1589-1382$ & $1589-1382$ & $1589-1382$ & C-O stretching of Calcite \\
$1080-1175$ & 1082 & 1082 & 1083 & 1075 & Si-O asymmetrical stretching vibration of quartz \\
$1035-30$ & 1030 & 1035 & 1040 & 1026 & Si-O stretching (clay minerals) \\
$\sim 915$ & - & - & 912.4 & - & O-H deformation linked to $2 \mathrm{Al}^{3+}$ \\
$880-865$ & 875 & 882 & 875 & - & O-H deformation linked to Al ${ }^{3+}$, Mg $^{2+}$ \\
$800-780$ & 794 & 797 & 796 & 793 & Si-O symmetrical stretching vibration of quartz \\
$\sim 784$ & 784 & 779 & 778 & 778 & Al-OH translational vibration \\
$700-690$ & 696.1 & 689.9 & 696.9 & 683 & Si-O symmetric bending vibration of quarts \\
$\sim 620$ & 600 & - & - & 610 & O-Al-O bending \\
$\sim 535$ & 523 & 528 & 521 & 530 & (Fe-O, Fe $\mathrm{O}_{3}$ ) Si-O-Al stretching \\
$480-470$ & 467.4 & 474 & 476 & 480.6 & Si-O-Si bending mode \\
\hline
\end{tabular}



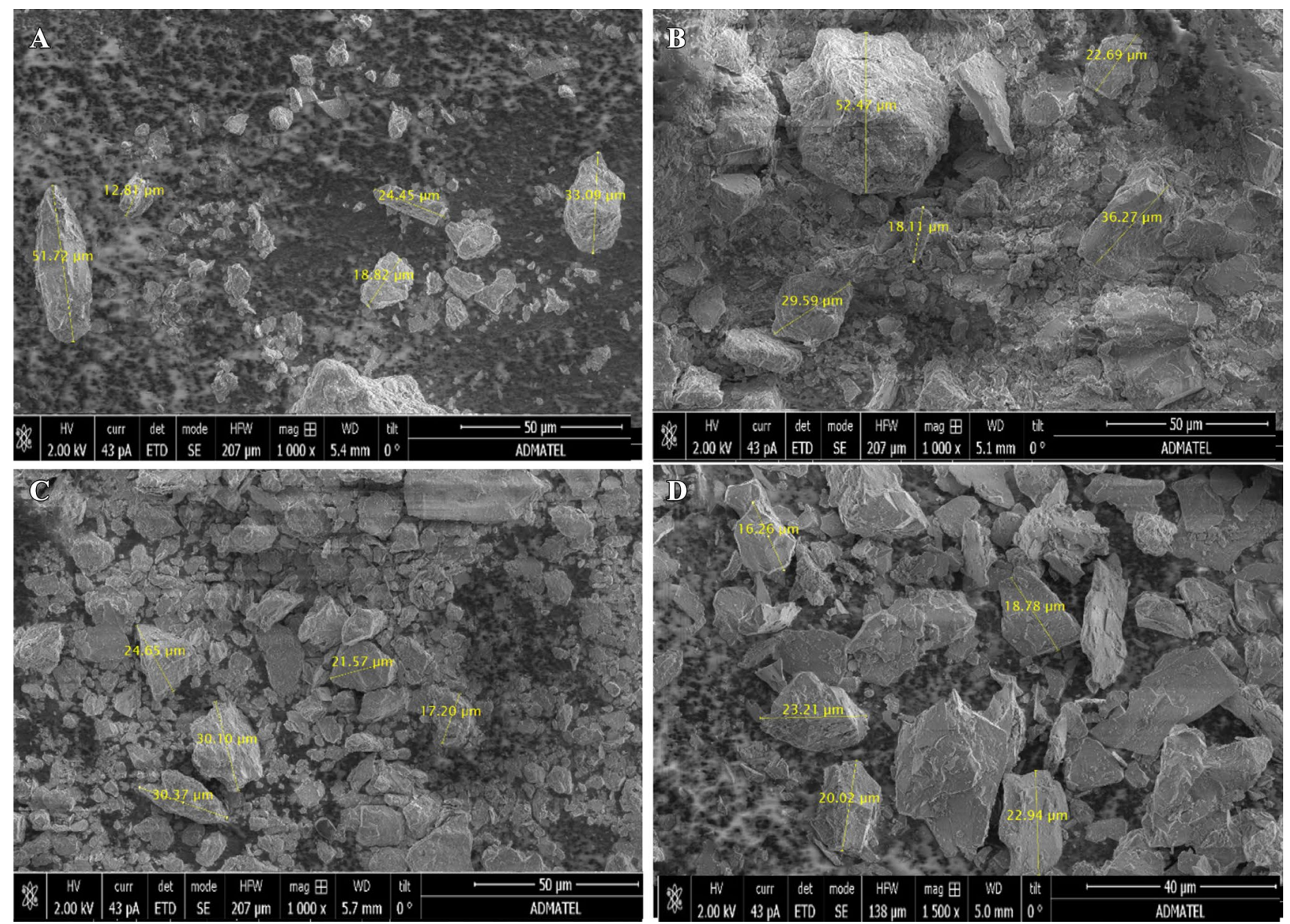

Fig. 3 Photomicrographs of particles in a W-CIP, b D-CIP and c D-BM at $1000 \times$ magnifications as well as sample $\mathbf{d}$ Li-BM at $1500 \times$ magnification

still the most abundant element in all of the samples detected by EDS followed by aluminum and iron. Table 4

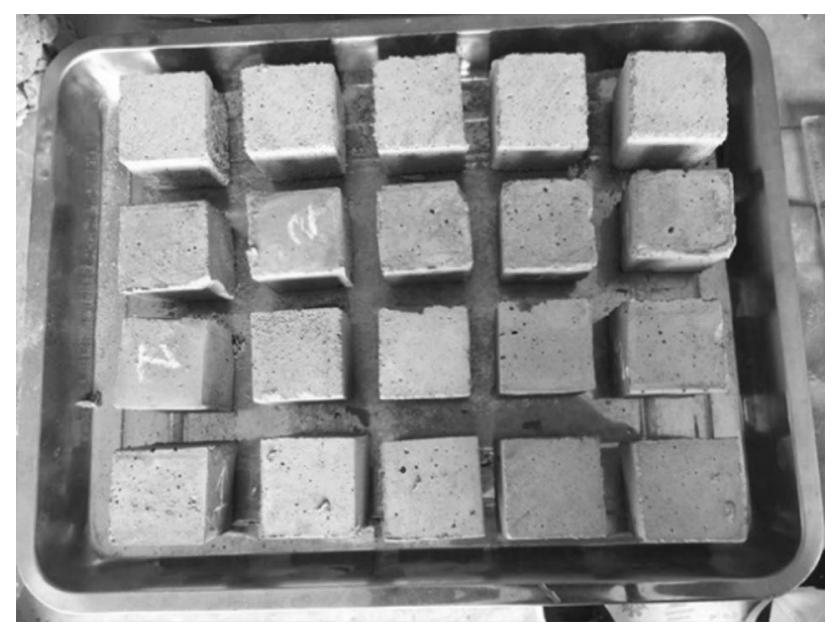

Fig. 4 Geopolymer cubes cured in ambient condition for 7 days prior to compression test shows the trace elements detected in the gold-mine tailings samples using EDS.

\subsection{Mechanical properties of gold-mine tailings after geopolymerization}

The exploratory synthesis of geopolymer utilizing goldmine tailings after CIP process and with $\mathrm{Si}-\mathrm{Al}$ ratio close

Table 4 Elemental composition of the mine tailings

\begin{tabular}{lcccc}
\hline Element & Li-BM & P-CIP & W-BM & W-CIP \\
\hline $\mathrm{O}$ & 44.2 & 39.9 & 44.8 & 40.3 \\
$\mathrm{Si}$ & 29.3 & 15.6 & 28.0 & 22.8 \\
$\mathrm{Fe}$ & 2.53 & 16.5 & 1.05 & 1.98 \\
$\mathrm{Al}$ & 3.18 & 4.55 & 1.75 & 2.80 \\
$\mathrm{Mg}$ & 1.40 & 1.30 & 0.20 & 0.32 \\
$\mathrm{~K}$ & 0.15 & 2.93 & 0.12 & 1.05 \\
$\mathrm{Ca}$ & 0.20 & 0.08 & 1.10 & 1.03 \\
\hline
\end{tabular}


to recommended value was successfully carried out. After 7 days of curing, as shown in Fig. 4, the gold-mine tailingsbased geopolymer cubes gained an average compressive strength of $5.48 \mathrm{MPa}$ and a maximum compressive strength of $5.95 \mathrm{MPa}$. These results were remarkably higher compared with the results of [43] which only obtained a compressive strength less than $5 \mathrm{MPa}$. These authors, however, used $5 \mathrm{M} \mathrm{NaOH}$ solution as alkali activator. The higher compressive strength of synthesised geopolymer in this study could be attributed to the higher amounts of calcium hydroxide produced from the reaction of sodium hydroxide and calcium carbonate in lime sludge. This calcium hydroxide most likely accelerated both geopolymerization and pozzolanic reaction that formed more geopolymers and hydration products. Also, the carbonates could act as filler material and contribute to the increase in compressive strength of the final product [21]. The curing temperature is an important factor to the strength of geopolymer considering that that rate of reaction affects the over-all reaction mechanism. In this study, the geopolymer undergone ambient conditions with temperatures ranging from 23 to $32^{\circ} \mathrm{C}$, although having lower compressive strength compared to elevated temperature [44], it is more economical and practical at this condition with regards to the synthesis of geopolymer.

\section{Conclusions}

The results presented in this study provide vital information for the possible utilization of gold-mine tailings as geopolymer source materials. Based on the chemical and mineral compositions of the tailings, this waste material could be used as geopolymer source materials but some additives may have to be introduced for the optimum development of mechanical properties. In addition, alumino-silicate minerals such as illite, kaolinite and zeolite, which are known to geopolymerise by adding certain alkali activators (e.g., $\mathrm{Ca}(\mathrm{OH})_{2}, \mathrm{NaOH}$ and $\mathrm{NaOH}+\mathrm{NaSiO}_{3}$ ) were detected in the samples. The tailing samples with relatively high $\mathrm{Si}-\mathrm{Al}$ ratios (W-CIP, Li-BM and W-BM) could be improved by blending with aluminum-rich additives to adjust the $\mathrm{Si}-\mathrm{Al}$ ratio to the optimum value needed during geopolymerization or probably explore their potential use as mixed alkali activator considering that they contain substantial amounts of $\mathrm{CaO}$, which could be further developed into a kind of "hybrid" cement-geopolymer material. It is important to take into consideration the possible effects of other $\mathrm{Al}$ and Si-containing minerals such as vermiculite, muscovite and pyrophyllite on dissolution during activation and geopolymerization. Moreover, the adequate compressive strength of this hybrid material with low density satisfy the future construction application of lightweight material. The advantages of a lightweight material for construction are having better structural integrity as well as thermal and sound insulation properties [45]. Finally, the gold-mine tailings were successfully used as geopolymer source materials with relatively high compressive strength using a lime sludge-based powder activator.

Acknowledgements The authors would like to thank the local government units of Barangay Gango, Libona, Bukidnon and Barangay Mt. Diwata, Monkayo, Compostela Valley for their assistance in the collection of the samples. Special acknowledgments are also due to Dr. James V. Presbitero of Caraga State University and Engr. Jemima R. Perodes for their helpful discussion and support in the conduct of the study.

Funding The authors disclosed the receipt of the following financial support for the research, authorship, and/or publication of this article: The authors would like to thank the Department of Science and Technology_Philippine Council for Industry, Energy and Emerging Technology Research and Development (DOST-PCIEERD) for funding and Central Mindanao University as implementing agency for the support in the conduct of the study.

\section{Compliance with ethical standards}

Conflict of interest The authors declared no potential conflicts of interest with respect to the research, authorship and/or publication of this article.

\section{References}

1. Board of Investments (BOI) (2011) The Philippines' mineral potential. Retrieved from http://www.investphilippines.gov. ph/downloads/sector/Mining.pdf. Accessed 11 May 2018

2. Philippine Statistics Authority (PSA) (2017) Estimation of production, tons mined and tailing generated by the small-scale gold mining activities. https://psa.gov.ph/content/estimation -production-tons-mined-and-tailing-generated-small-scale -gold-mining-activities. Accessed 11 May 2018

3. Opiso EM, Aseniero JP, Banda MT, Tabelin CB (2018) Solid-phase partitioning of mercury in artisanal gold mine tailings from selected key areas in Mindanao, Philippines, and its implications for mercury detoxification. Waste Manag Res 36:269-276. https ://doi.org/10.1177/0734242×17753534

4. Thakur AK, Pappu A, Thakur VK (2018) Resource efficiency impact on marble waste recycling towards sustainable green construction materials. Curr Opin Green Sustain Chem 13:91101. https://doi.org/10.1016/j.cogsc.2018.06.005

5. Kawade U, Rathi V, Girge VD (2013) Effect of use of bagasse ash on strength of concrete. Int J Innov Res Sci Eng Technol 2:2997-3000

6. Ahmari S, Zhang L (2012) Production of eco-friendly bricks from copper mine tailings through geopolymerization. Constr Build Mater 29:323-331

7. Zhang L, Ahmari S, Zhang J (2011) Synthesis and characterization of fly ash modified mine-tailings based geopolymers. Constr Build Mater 25:3773-3781

8. Kunt K, Yildirim M, Dur F et al (2013) Utilization of Bergama gold tailing as an additive in the mortar. CBU J Sci 11:365-371 
9. Tariq A, Yanful EK (2013) A review of binders used in cemented paste tailings for underground and surface disposal practices. $J$ Environ Manag 131:138-149

10. Yagüe $S$ et al (2018) Coal-mining tailings as a pozzolanic material in cements industry. Minerals 8:46. https://doi.org/10.3390/ $\min 8020046$

11. Celik O, Piskin IYE (2006) Utilization of gold tailings as an additive in Portland cement. Int Solid Waste Assoc 24:215-224

12. Roy S, Adhikari GR, Gupta RN (2007) Use of gold mill tailings in making bricks: a feasibility study. Int Solid Waste Assoc 25:475482. https://doi.org/10.1016/j.jafrearsci.2017.10.016

13. Komnitsas K, Zaharaki D (2007) Geopolymerisation: a review and prospects for the minerals. Miner Eng 20:1261-1277

14. Yunsheng Z, Wei S, Qianli C, Lin C (2007) Synthesis and heavy metal immobilization behaviors of slag based geopolymer. J Hazard Mater 143(1-2):206-213

15. El-Eswed BI, Yousef Rl, Alshaaer M et al (2015) Stabilization/solidification of heavy metals in kaolin/zeolite based geopolymers. Int J Miner Process 137:34-42

16. Cheng TW, Lee ML, Ko MS et al (2012) The heavy metal adsorption characteristics on metakaolin-based geopolymer. Appl Clay Sci 56:90-96

17. Gitari MW, Akinyemi SA, Thobakgale R et al (2017) Physicochemical and mineralogical characterization of musina mine copper and new onion gold mine tailings: implications for fabrication of beneficial geopolymeric construction of materials. J Afr Earth Sci 137:218-228. https://doi.org/10.1016/j.jafrearsci.2017.10.016

18. Caballero E, Sanchez W, Rios C (2014) Synthesis of geopolymers from alkaline activation of gold mining waste. Ing Compet 16:317-330

19. Ren X, Zhang L, Ramey D et al (2014) Utilization of aluminum sludge (AS) to enhance mine tailings-based geopolymer. J Mater, Sci

20. Ahmari S, Zhang L (2013) Utilization of cement kiln dust (CKD) to enhance mine tailings-based geopolymer bricks. Constr Build Mater 40:1002-1011

21. Reddy MS, Dinakar P, Rao BH (2016) A review of the influence of source material's oxide composition on the compressive strength of geopolymer concrete. Microporous Mesoporous Mater 234:12-23. https://doi.org/10.1016/j.micro meso.2016.07.005

22. Celik IB (2009) The effects of particle size distribution and surface area upon cement strength development. Powder Technol 188:272-276

23. Abdel-Gawwad HA, Abo-El-Enein SA (2014) A novel method to produce dry geopolymer cement powder. Hous Build Natl Res Cent HBRC J 12:13-24

24. Oh JE, Monteiro PJM, Jun SS et al (2010) The evolution of strength and crystalline phase for alkali-activated ground blast furnace slag and fly ash-based geopolymers. Cem Concr Res 40:189-196

25. Kumar S, Djobo JNY, Kumar A et al (2016) Geopolymerization behavior of fine iron-rich fraction of brown fly ash. J Build Eng 8:172-178

26. Lemougna PN (2013) The role of iron in the formation of inorganic polymers (geopolymers) from volcanic ash: a 57Fe Mössbauer spectroscopy study. J Mater Sci 48:5280-5286. https://doi. org/10.1007/s10853-013-7319-4

27. Davidovits F, Davidovits J, Davidovits M (2013) Geopolymer cement of the calcium ferro-aluminosilicate polymer type and production process. Patent WO2012056125A1
28. Xu H, Deventer JSJ (2000) The geopolymerization of aluminosilicate minerals. Int J Miner Process 59:247-266

29. Heah CY, Kamarudin H, Al Bakri AMM et al (2011) Effect of curing profile on kaolin-based geopolymers. Phys Proc 22:305-311

30. Okoye KN, Durgaprasad J, Singh NB (2015) Fly ash/kaolin based geopolymer green concretes and their mechanical properties. Data Brief 5:739-744

31. Nikolov A, Rostovsky I, Nugteren H (2017) The geopolymer materials based on natural zeolite. Constr Mater 6:198-205. https://doi.org/10.1016/j.cscm.2017.03.001

32. Villa C, Pecina ET, Torres R et al (2010) Geopolymer synthesis using alkaline activation of natural zeolite. Constr Build Mater 24:2084-2090

33. Heah CY, Kamarudin H, Al Bakri AMM et al (2013) Kaolin-based geopolymers with various $\mathrm{NaOH}$ concentrations. Int J Miner Metall Mater 20:313-322. https://doi.org/10.1007/s1261 3-013-0729-0

34. Saikia BJ, Parthasarathy G, Sarmah NC (2008) Fourier transform infrared spectroscopic estimation of crystallinity in $\mathrm{SiO}_{2}$ based rocks. Bull Mater Sci 31:775-779

35. Li C, Fu L, Ouyang J et al (2015) Kaolinite stabilized paraffin composite phase change materials for thermal energy storage. Appl Clay Sci 115:212-220

36. Li C, Zeng L, Fu H et al (2017) Mineralogical and chemical characteristics of the lead-zinc tailing and contaminated soil from the mine tailing pond in Human Province (China). Physicochem Probl Miner Process 53:1133-1147

37. Voll D, Angerer P, Beran A et al (2002) A new assignment of IR vibrational modes in mullite. Vib Spectrosc 30:237-243

38. Tabelin CB, Sasaki R, Igarashi T et al (2017) Simultaneous leaching of arsenite, arsenate, selenite and selenate, and their migration in tunnel-excavated sedimentary rocks: I. Column experiments under intermittent and unsaturated flow. Chemosphere 186:558-569

39. Saikia BJ, Parthasarathy G (2010) Fourier transform infrared spectroscopic characterization of kaolinite from Assam and Meghalaya. Northeastern India. J Mod Phys 1:206. https://doi. org/10.4236/jmp.2010.14031

40. Tabelin CB, Veerawattananun S, Ito M et al (2017) Pyrite oxidation in the presence of hematite and alumina: I. Batch leaching experiments and kinetic modeling calculations. Sci Total Environ 580:687-698

41. Hanna R (1965) Infrared absorption spectrum of silicon dioxide. J Am Ceram Soc 48:595-599. https://doi. org/10.1111/j.1151-2916.1965.tb14680.x

42. Adajar MQ, Zarco MH (2012) Compressibility and hydrocompression settlement of mine tailings. Geotechnical Engineering Group, Institute of Civil Engineering, University of the Philippines Diliman, Quezon City

43. Kiventera J, Golek L, Yliniemi J et al (2016) Utilization of sulphidic tailings from gold mine as a raw material in geopolymerization. Int J Miner Process 149:104-110

44. Okoye FN (2017) Geopolymer binder: a veritable alternative to Portland cement. Mater Today Proc 4:5599-5604

45. Roviello G, Menna C, Tarallo O, Ricciotti L, Messina F, Ferone C, Asprone D, Cioffi R (2017) Lightweight geopolymer-based hybrid materials. Compos Parts B 128:225-237. https://doi. org/10.1016/j.compostiesb.2017.07.020 